\title{
LKTs as a means of learning English for specific purposes in a virtual modality
}

\section{Las TAC como medio para aprender inglés con propósitos específicos en modalidad virtual}

FLORES-GONZÁLEZ, Norma†*

Benemérita Universidad Autónoma de Puebla, Faculty of Languages, Mexico.

ID $1^{\text {st }}$ Author: Norma, Flores-González / ORC ID: 0000-0002-4967-8854, Researcher ID Thomson: S-6917-2018, CVU CONACYT ID: 957036

\begin{abstract}
Learning English implies developing oral, writing, reading, and listening competencies in real contexts to avoid its isolated conceptualization for appropriate communication since the meaning and interpretation of language deal with Semantics and Pragmatics. The study focussed on these objectives: identify the learning and knowledge technologies (LKTs) used in the Semantics and Pragmatics course; know the subjects' perceptions concerning their usage and the findings obtained from their application. Methodologically, a descriptive longitudinal quantitative approach took place, getting these results: identification of LKT resources to promote writing, oral, listening, and reading competencies focused on Semantics and Pragmatics, description of students' perception regarding LKT resources characterized as triggers motivational to learn collaboratively with a positive attitude in their use. The study corroborated that this proposal let subjects grasp the meaning and interpretation of language and achieve a higher proficiency level. In conclusion, LKTs represent a potentially ideal means of learning the language in virtual environments, understanding how they work in context, and acquiring key fundamentals to communicate successfully.
\end{abstract}

LKTs, learning English, virtual environment

\begin{abstract}
Resumen
Aprender inglés implica desarrollar la competencia oral, escrita, lectora y auditiva en contextos reales evitando su conceptualización aislada, para una comunicación aceptable ya que el significado e interpretación del lenguaje está mediado por la Semántica y la Pragmática. El objetivo del estudio es identificar las tecnologías del aprendizaje y de conocimiento (TAC) utilizadas en el curso de Semántica y Pragmática, conocer la caracterización de los sujetos con respecto a su uso y los resultados obtenidos a partir de su aplicación. Metodologicamente se recurrió al enfoque cuantitativo longitudinal descriptivo encontrando estos resultados: identificación de recursos TAC para promover la competencia escrita, oral, auditiva y lectora enfocadas a la Semántica y Pragmática, descripción de la percepción de los sujetos con respecto a los recursos TAC caracterizados como detonadores motivacionales para aprender colaborativamente con actitud positiva en su uso. También se corroboró que esta propuesta permitió a los sujetos aprender el significado e interpretación del lenguaje y alcanzar un mayor nivel de proficiencia en el idioma. En conclusión, las TAC representan un medio potencialmente idóneo para aprender el idioma en ambientes virtuales, comprender cómo funciona en contexto y adquirir fundamentos clave para comunicarse exitosamente.
\end{abstract}

TAC, aprendizaje del inglés, ambiente virtual

Citation: FLORES-GONZÁLEZ, Norma. LKTs as a means of learning English for specific purposes in a virtual modality. Journal of Information Technologies and Communications. 2020. 4-13:23-32.

\footnotetext{
* Correspondence to Author (E-mail: norma-fg@ hotmail.com)

$\dagger$ Researcher contributing as first author.
} 


\section{Introduction}

The contingency that the world is facing derived from the COVID 19 pandemic has revolutionized the way of living, education, and specifically, the teaching-learning process.

The educational system in Mexico has chosen to teach distance classes with the support of learning and knowledge technologies, television programs, the internet, and materials that each teacher from his specialty considers a viable resource for this purpose. In that attempt, higher education institutions have adopted platforms to share content and carry out both synchronous and asynchronous sessions. Nonetheless, institutions and teachers have been overwhelmed by the demands of distance courses that require ad hoc teaching practices to fulfill the purpose of teaching and learning. One of the main obstacles focuses on the selection of learning and knowledge technologies for the design of instructional content appropriate to the proficiency level of students, their learning styles, cognitive, metacognitive, and selfregulation strategies since definitely, the majority of teachers who incorporate information and communication technologies (ICT) use them as a tool without integrating them into pedagogy. In this respect, various studies show that ICT usage in the classroom is low in Europe and North America (OECD, 2004; Bauer and Kenton, 2005; Kessel et al., 2005; Becta, 2006); additionally, Mexico is not an exception.

What is needed is not only the inclusion of ICT in the educational field but also LKTs, which support the redirection of their pedagogical use for an adequate technopedagogical design, the selection of technological tools for the generation of synchronous and asynchronous audio-visual resources and learning objects operable on platforms to facilitate the students' teachinglearning process.

In the case of the School of Languages of the Universidad Autónoma de Puebla, specifically in the Semantics and Pragmatics class (context of this research), a study was carried out to identify the learning and knowledge technologies used in the technopedagogical design of said subject, the subjects' characterization concerning their usage and the underlying results from their application.
Based on the previous objectives, the following research questions guided this study:

a) What were the learning and knowledge technologies used in the techno-pedagogical design?

b) what were the subjects' perceptions regarding their usage during the Semantic and Pragmatic course in fall 2020 ?

c) what were the results from the application of LKTs?

\section{Theoretical framework}

\section{Learning and Knowledge Technologies (LKTs)}

The implementation of technology has modified the teaching dynamics, as it breaks with routine and mechanical work. Besides, it meets students' needs as digital natives, which favors the inclusion of these technologies.

On the one hand, the development of skills in a foreign language requires the design of closely linked activities that privilege the use of cognitive, metacognitive, and self-regulation strategies with a specific purpose, avoiding rote learning. On the other hand, said design must be perfectly aligned with continuous and formative planning and evaluation of its actors: students and teachers (Casanova, 2009).

According to the literature review, for different authors (Balanskat, Blamire \& Kefala, 2006; Galanouli, Murphy \& Gardner, 2004; Orellana, Almerich, Belloch, \& Díaz, 2004), the teachers who incorporate LKTs in the teaching process must have positive attitudes towards their integration. Thus, as teachers, we must face this challenge, meet these technological needs and innovate in the teaching English process.

In this context, the innovation factor is decisive to make the difference between a passive and mechanical or active class with meaningful learning to achieve the purposes established in an English class since this does not depend solely on the technological resource used in it, but rather the techno-pedagogical design carried out by the teacher because he is responsible for directing the digital tools. 
At this point, Cortes-Ocaña (2013) explores various technological resources and makes contributions to the inclusion of LKTs as a need that demands a change in the roles of educational actors by requiring new competencies to use technologies in educational environments. She also highlights that the implementation of LKTs in didactic planning is necessary to achieve pedagogical excellence because they become generators of didactic activities that enhance fundamental English skills and knowledge.

Gualdrón (2015) suggests that LKTs are new ways that provide possible uses of ICT in education with a pedagogical added value. The author affirms that the pedagogical implementation of ICT transforms teachers into an LKT instrument to the deconstruction of English knowledge. She also ensures that knowing ICT provides teachers skills to implement pedagogical technologies in-class activities and achieve the learning purposes. Moreover, it allows students to appropriate, understand, improve and streamline their learning process.

For Cabrero (2015), LKT is the implementation of ICT as learning tools and knowledge production. According to Enríquez (2012), as cited in Pinto, Díaz \& Alfaro (2016, p. 40), "they are the product of the genuine and meaningful uses of ICT, intending to improve learning, creating dynamics and training practices that compromise the investigation of the various didactic usages of digital technology".

Regarding the above, the implementation of ICT under a pedagogical scheme makes the student take responsibility for their learning process, and the teacher adapt the use of LKTs in their didactic planning, providing students with a dynamic tool of the educational process.

According to Delgado (2019), LKTs promote change in learning the English language and affirms that the teacher is responsible for developing planning based on didactic strategies to achieve the established purposes. Likewise, the author considers that learning English requires the activation of various senses, which can be stimulated by the implementation of LKTs.
IEAE (2007), Korte and Hüsing (2006) point out that the LKTs promote values, which motivate the student by creating an interactive environment, stimulating their senses, providing innovative and attractive spaces, promoting the learning and achievement of English skills.

The implementations of LKTs in content or general courses and didactic plannings promote fundamental skills such as the ability to process information, develop writing and reading skills in a dynamic, interactive, and innovative way (Marqués, 2000).

\section{Learning English in a virtual environment}

Virtual education involves technology implementation to meet digital needs and positively contribute to student learning and performance.

Besides, its application requires different elements like a rigorous process of selecting LKT resources, adapt them to didactic planning, rethinking the roles of educational actors (teacher and students), and the most important, willingness to make such a remarkable change. Pastor (2005) affirms that virtual education has a double intention: cause and consequence for a change.

A virtual environment creates an ideal environment for relationships. For that reason, it must be treated in a different way to achieve its effectiveness (Duart, n.d.). It leads to synchronous or asynchronous communication in another space than the classroom for intentional training purposes that promote autonomous learning and thinking (Unigarro, 2001).

For Zuñiga \& Carrasco (2012), the materials or resources to be implemented and the availability of technology are the main elements in virtual education as a means of communication per se between the studentteacher and the tool to appropriate knowledge.

In the case of learning English in the virtual modality, studies conducted by Soto (2019) and Román (2017) conclude that students who learned the English language through a virtual environment recognize that the effectiveness of their learning depends on wellstructured content easy to understand, distribution of time, discipline and selfmotivation. 
For Ávila, Arnaiz \& Arias (2015), the practice of English in virtual environments demands constant interaction between students with the implementation of Web tools that request tasks according to the established purposes and contribute to the development of oral communicative competence of English.

Besides, on the one hand, according to Nguyen (2010), for learning English virtually, the communicative approach is essential because this implies addressing contextualized, meaningful, and original learning activities. On the other hand, Corrales (2009) affirms that adapted linguistic input must attend to study students' needs, purposes, and previous knowledge to help them work on those particular spaces.

Chaves, Chaves, and Rojas (2015) point out that innovative strategies to learn English in a virtual environment meet learning needs, develop multiple intelligences and promote different learning styles because they also build and reconstruct knowledge, foster communication skills, critical thinking, and favor an academic performance.

Another of the benefits of the virtual modality is that students control the environment that satisfactorily influences their language learning process, self-manage the time they spend to carry out learning tasks, and generate a meta-cognitive self-regulation process (Marulanda, Ramírez, Londoño \& López, 2018).

According to Saavedra \& Robledo (2016), virtual learning promotes cognitive skills such as creating, applying, understanding, knowing, and analyzing; indicators that motivate students to read, write, express their points of view and awaken their creativity in the learning process.

According to the studies mentioned above, theoretically, LKTs represent a viable instrument for teaching virtual classes and learning a language for either specific or general purposes, all under a techno-pedagogical design.

\section{Methodology}

For analyzing this study phenomenon, the quantitative approach of longitudinal cut and descriptive scope was used during the autumn period of 2020, taking into account that this allows an objective analysis concerning a social fact using questionnaires, representation of results in tables or graphs (Rodríguez Peñuelas, 2010) and statistical analysis (Hernández, Fernández, and Baptista, 2010).

The sample consisted of 30 subjects belonging to the same semester of the educational program with synchronous and asynchronous virtual classes 4 hours a week in each modality, respectively.

\section{Analysis model}

The previous research questions are the basis of the analysis model.

\begin{tabular}{|c|c|}
\hline Research question & Instrument \\
\hline $\begin{array}{l}\text { What were the learning } \\
\text { and knowledge } \\
\text { technologies (LKTs) } \\
\text { used in the techno- } \\
\text { pedagogical design? }\end{array}$ & $\begin{array}{l}\text { Analysis of the techno- } \\
\text { pedagogical design } \\
\text { and identification of } \\
\text { LKTs. }\end{array}$ \\
\hline $\begin{array}{l}\text { What were the subjects' } \\
\text { perceptions regarding } \\
\text { the use of LKTs during } \\
\text { the course in fall 2020? }\end{array}$ & $\begin{array}{l}\text { A Likert-type scale } \\
\text { questionnaire took } \\
\text { place to measure the } \\
\text { subjects' perceptions } \\
\text { regarding the degree of } \\
\text { usefulness of the LKT } \\
\text { resources to learn } \\
\text { Semantics and } \\
\text { Pragmatics, and in } \\
\text { general, English as a } \\
\text { foreign language. }\end{array}$ \\
\hline $\begin{array}{l}\text { What were the results } \\
\text { from the application of } \\
\text { LKTs? }\end{array}$ & $\begin{array}{l}\text { Subjects took a } \\
\text { standardized test to } \\
\text { measure their } \\
\text { proficiency before } \\
\text { learning with the } \\
\text { techno-pedagogical } \\
\text { design and after it. }\end{array}$ \\
\hline
\end{tabular}

Table 1 Analysis model

Source: Own elaboration

The data collection process is detailed below.

1. The standardized test was applied to know the level of proficiency before starting to work with the pedagogical design.

2. The LKTs used in the course were identified through a detailed analysis of the technopedagogical design.

FLORES-GONZÁLEZ, Norma. LKTs as a means of learning English for specific purposes in a virtual modality. Journal of Information Technologies and Communications. 2020 
3. After identifying the LKTs used in the course, a 50-item Likert-type scale questionnaire was designed and applied to subjects to know their perceptions of the LKTs.

4. The standardized test was applied again to realize the underlying results of the application of LKTs in the teaching-learning process.

\section{Findings}

These are the results from the previous analysis model.

\section{Learning and knowledge technologies (LKTs) used in the techno-pedagogical design}

In the Semantics and Pragmatics course, subjects used various LKT resources to learn the meanings of words in different contexts, and as a result, the interpretation of the language.

\begin{tabular}{|l|l|}
\hline \multicolumn{1}{|c|}{ Competence } & \multicolumn{1}{|c|}{$\begin{array}{c}\text { LKT resources to learn semantic } \\
\text { and pragmatic fundamentals }\end{array}$} \\
\hline Oral & $\begin{array}{l}\text { Quick, 123 apps, zoom, blogger, and } \\
\text { Edpuzzle }\end{array}$ \\
\hline Writing & $\begin{array}{l}\text { Google Docs, Padlet, Microsoft } \\
\text { Teams, Pixton, and Storybird }\end{array}$ \\
\hline Listening & Vocaroo, PodBean, and Audacity \\
\hline Reading & Piktochard, Easel.ly, and Genial.ly \\
\hline
\end{tabular}

Table 2 Learning and knowledge technologies used in the techno-pedagogical design

Subjects' perceptions regarding the use of LKTs used in the techno-pedagogical design during the Semantics and Pragmatics course, Fall 2020

\section{Oral competence}

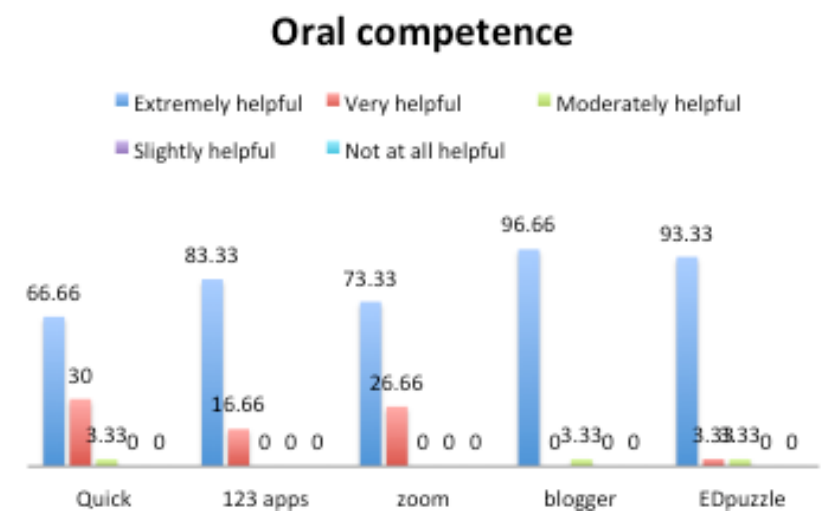

Figure 1 Oral competence
As can be seen, most of the sample perceived LKT resources as extremely helpful tools in their process of learning semantic and pragmatic elements.

Subjects indicate that LKT resources satisfy their audio-visual learning style and foster their learning process. It corroborates the results from Flores-González' study (2020), which mentions the necessity to align an instructional design mediated by ICT to the content pedagogically to engage students on authentic-interactive activities in their learning process.

Regarding the Quick digital video tool, $66.66 \%$ stated that it is extremely helpful, $30 \%$ very helpful, and 3.33 moderately helpful. In this case, the subjects pointed out that the app is easy to use for creating situational videos that enrich their learning process and let portability of audio-visual materials at different times, platforms or repositories.

About the 123 app resource, $83.33 \%$ described it as extremely helpful, and $16.66 \%$ as very helpful for developing oral competence and learning about semantic relationships in authentic and non-authentic contexts. It is worth mentioning that the most remarkable features of this tool are the single browser and its benefits to edit, modify or combine audio and video.

Moreover, $73.33 \%$ of the subjects pointed to Zoom as an extremely helpful tool and $26.66 \%$ as moderately helpful because, during the practice of oral competence, it allowed them to select the correct register or code and apply suitable norms to each situational issue and context (courtesy, irony, or humor), attitudes, and formal knowledge in addition to using nonverbal language as support for their discourse due to its video and audio modality.

Blogger was the LKT resource perceived as the most useful by the sample, which indicates that the design of the activities based on the LKTs guided the subjects to identify their communicative and receptor intention to use the appropriate resources (system interdependent codes) for successful oral communication.

Finally, EDpuzzle was the second LKT resource identified as extremely useful for learning semantic and pragmatic content in the oral competence. 
The subjects indicated that their benefits of editing videos represent ad hoc means for learning and analyzing semantic and pragmatic foundations in real and natural situations or for modifying the videos available on the web for educational purposes, which support the comprehension of the above-stated elements promoting their identification at the time of use.

\section{Writing Competence}

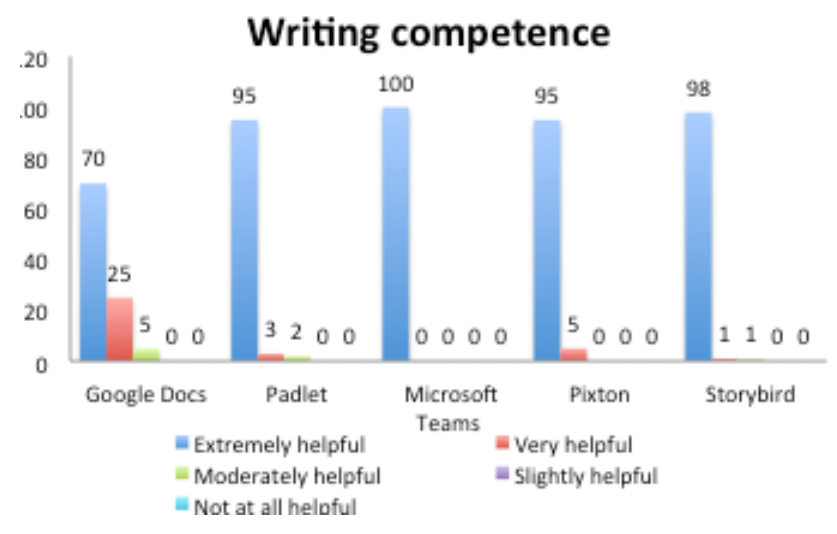

Figure 2 Writing competence

The figure points out the Google Docs tool as useful (95\%) to promote collaborative work in the construction of pragmatic writings to show how the context, interpersonal relationships, and the prior knowledge of the actors influence the interpretation of the meaning of language by using free digital tools available on the web. Indeed, the subjects assert that the app motivated interactive work and collaborative learning in virtuality, as pointed out by Ávila, Arnaiz \& Arias (2015), Korte and Hüsing (2006), and IEAE (2007).

Regarding the Padlet resource, $98 \%$ of the sample consider it as a useful means to energize classes and turn a theoretical session into something more practical with meaningful and collaborative learning with elements of text, photos, video, and audio to satisfy the subjects' learning styles, the center of the teachinglearning process in the present research and techno-pedagogical design.

The Pixton app represented $95 \%$ of usefulness for the subjects when writing with humorous, ironic, and persuasive overtones, evidencing semantic and pragmatic foundations appropriate to the situations of each scene of the comics. However, the Storybird app was considered more useful compared to the previous one (98\%).
The results also show that learning English requires the decoding and encoding texts from pragmatic elements to achieve suitable written communication.

Finally, the Microsoft Teams platform linked to the present techno-pedagogical design was conceptualized by $100 \%$ of the sample as extremely helpful in the proper choice of semantics to express irony, courtesy, metaphorical and poetic language unambiguously in writing.

\section{Listening competence}

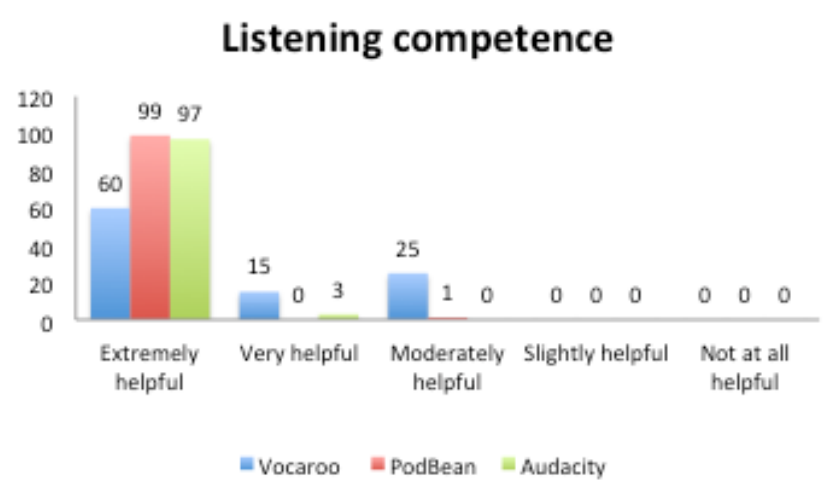

Figure 3 Listening competence

According to the figure, three LKT resources are essential for learning semantic and pragmatic principles orally: vocaroo, audacity, and podBen.

In the particular case of vocaroo, on the one hand, $75 \%$ of the sample recognized it as a useful app, especially to promote pragmatic aspects in conversations and use the language in communicative, social, and situational contexts authentically and naturally. On the other hand, $25 \%$ considered it as moderately helpful that implies this LKT resource does promote subjects' learning process proactively with bold and creative actions to generate meaningful and meta-cognitive learning.

Regarding audacity, 97\% identified it as extremely helpful and 3\% as very helpful respectively due to the advantages it offers to edit audio in real-time with sound effects such as echo, tone, and inversion, which allowed to create real situations with suitable semantic and pragmatic elements, communicate what the sender really wanted and thus, obtain an objective interpretation of the messages by the receivers. 
PodBean was the most accepted (99\%), concerning its usefulness, thanks to its ease of use, functions as a video, audio blog creator, and aggregator.

These results confirm the assertions of Serra et al. (2000) regarding the importance of pragmatics in the communicative act by describing it as the skills, linguistic and cognitive knowledge that leads to the proper use of the language in specific situations; essential aspects that can be taken to the field of virtual practice and learning through LKTs.

\section{Reading competence}

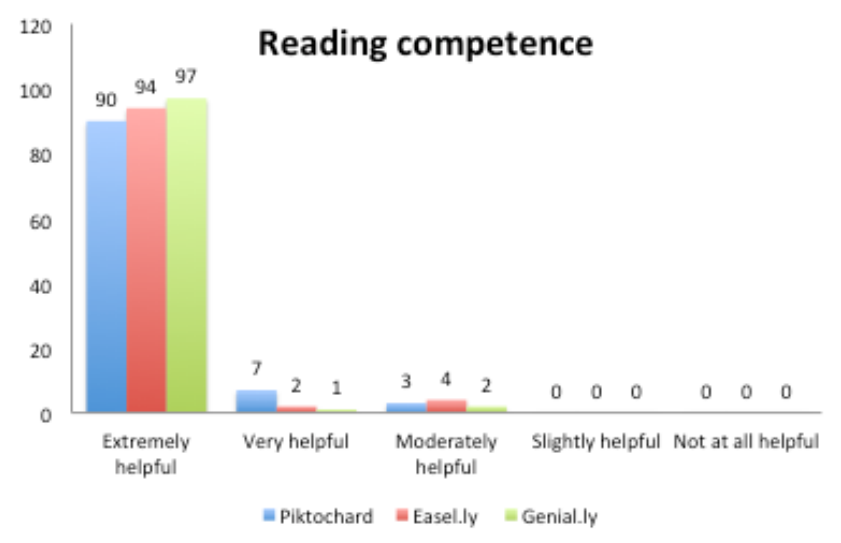

Figure 4 Reading competence

The information indicates that in the process of learning semantics and pragmatics with readings, subjects used three LKT resources: piktochart, easel.ly, and genial.ly

Piktochart registered $90 \%$ of usefulness according to the subjects' perceptions, followed by $7 \%$ as very helpful and $3 \%$ as moderately. It means that infographics contribute to the students' learning process because they can depict their comprehension of pragmatic and semantic concepts and highlight relationships between each element by using them.

Another app accepted as extremely helpful for acquiring and understanding knowledge was Easel.ly (94\%). This tool encourages the presentation of information on murals with a global perspective on the subject in a summarized way. Besides, it allows students to visually notice different semantic elements as reference, denotation, and development of lexical relationships between words, for instance, synonymy, antonymy, hyponymy, homonymy, polysemy, paronymy, metonymy, and placement.
Last but not least is Genial.ly. In this regard, $97 \%$ of the subjects indicated that it was helpful, and $2 \%$ moderately since it guided them in the analysis and synthesis of information for its visual presentation in a great variety of templates according to the topic. In reality, the sample perceived the format as a motivational tool (Saavedra \& Robledo, 2016) to develop cognitive skills, understanding, and learning about terms extracted from texts. For example, denotative, connotative, literal, and figurative meanings, deixis, speech acts, conversational implicature, courtesy, irony, and humor.

\section{Findings from the application of the LKTs}

A standardized test was applied to measure the subjects' proficiency and estimate the results of the application of LKTs with the learning of English as a target language.

The table shows the level they had at the beginning and the end of the course.

\section{Proficiency level}

\begin{tabular}{|l|l|l|l|}
\hline \multicolumn{2}{|c|}{ Before } & \multicolumn{2}{c|}{ After } \\
\hline Subjects & $\begin{array}{l}\text { Proficiency } \\
\text { level }\end{array}$ & Subjects & $\begin{array}{l}\text { Proficiency } \\
\text { level }\end{array}$ \\
\hline 12 & A2+ & 12 & B1 \\
\hline 13 & B1 & 9 & B2 \\
\cline { 3 - 4 } & & 4 & B2+ \\
\hline 5 & B1+ & 5 & B2+ \\
\hline
\end{tabular}

Table 3 Findings concerning the use of LKT resources in the learning process

The findings show a considerable improvement in the subjects' proficiency level of the target language. It implies that virtual learning environments focus on LKTs mediated by ICTs provide appropriate content to students according to their learning styles. They also develop an independent user and allow them to learn formative knowledge with specific purposes as in this research.

Finally, in this virtual modality, the teacher's guidance and support are essential to select information because the LKTs by themselves do not help them choose the appropriate one.

\section{Conclusions}

The following conclusions are drawn based on the results: 
In the first place, the study accomplished the three objectives and are described as followed: the learning and knowledge technologies used in the Semantics and Pragmatics course are 16 LKT resources grouped according to the competence they developed in each segment. There is also a subjects' characterization regarding the use and usefulness of LKTs, highlighting blogger, Microsoft Teams, audacity, and genial.ly for learning semantic and pragmatic fundamentals. Finally, the results obtained from the application of LKTs showed that the techno-pedagogical design also contributes to mastering the language as a target language.

Secondly, there is a high positive perception towards the use of LKTs, being evident in the students' work and activities, which show a greater fulfillment of tasks, proactive attitude, and high rate of correct exercises.

Third, these technologies are motivational activators to work and learn collaboratively in a virtual community.

Finally, the LKTs applied to virtual educational contexts represent a possibility to understand semantics and pragmatics, that is, the meaning and interpretation of language in varied contexts, and above all, meaningful for students.

\section{References}

Ávila, J. W. C., Arnaiz, N, Q., \& Arias, N. G. (2015). Aprender y enseñar: una propuesta pro virtual para el inglés en el contexto universitario actual. Revista Científica Sinapsis, 1(6).

Balank, A., Blamire, R. \& Kefala, S. (2006). The ICT impact report. A review of studies of ICT impact on schools in Europe. European Schoolnet. Recovered from: http://insinght.eun.org/shared/data/pdfimpact_st udy.pdf.

Bauer, J. \& Kenton, J. (2005). Toward technology integration in the schools: Why it isn't happening. Journal of Technology and Teacher Education, 13 (4), 519-546.
British Educational Communications and Technology Agency-Becta (2006). The Becta review 2006: evidence on the progress of ICT in education. Coventry, Inglaterra: Becta. Recovered from: http://deca.ioe.ac.uk/1427/1/becta_2006_bectar eview_report.pdf

Cabrero, J. (2015). Reflexiones educativas TIC, TAC, TEC: tecnología-ciencia-educación.com. Recuperado de tecnología-cienciaeducación.com Web site: http://www.tecnología-cienciaeducación.com/index.php/TCE/article/view/27/ 14

Casanova, M. A. (2009). Diseño curricular e innovación educativa. Madrid: La Muralla; $2^{\mathrm{a}}$ edición.

Chaves, O., Chaves, L. y Rojas, D. (2015). La realidad del uso de las TIC y su mediación pedagógica para enriquecer las clases de inglés. Revista ensayos pedagógicos, 10(1).

Corrales, W. K., (2009) Construyendo un segundo idioma. El constructivismo y la enseñanza del L2. Zona próxima, Número 10. ISSN electrónico: 2145-9444. Recovered from: http://rcientificas.uninorte.edu.co/index.php/zon a/article/viewArticle/1625/4657

Cortes-Ocaña, M. (2013). La integración de las TAC EN Educación (Bachelor's thesis).

Delgado, G. K. (2019). Las TAC como herramientas para el trabajo de aula en la asignatura de inglés para los estudiantes del colegio "Los Andes, Nuestra Señora de las Mercedes" de Pasto, Colombia.

Duart, J. M. (s.f.). Aprender sin distancias. Retrieved August 16, 2020, from UOC: http://www.uoc.edu/web/esp/articles/josep_mar ia_duart.html

Flores-González, N. (2020). Authenticinteractive activities to promote oral production on a virtual platform. Journal Applied Computing. 4 (15), 26-35. DOI: 10.35429/JCA.2020.15.4.26

Galanouli, D., Murphy, C. \& Gardner, J. (2004). Teachers' perception of the effectiveness of ICT-competence training. Computers and Education, 43, 63-79. 
Gualdrón, C. (2015). Competencias de docentes del área de humanidades para el paso de las TIC a las TAC: repository.usta.edu.co. Recovered from repository.usta.edu.co Web site: http://repository.usta.edu.co/bitstream/handle/1 1634/2935/gualdroncarmen2016.pdf?sequence $=1 \&$ isAllowed $=\mathrm{y}$

Hernández, S. R., Fernández, C.C. y Baptista, L. P. (2010). Metodología de la investigación. México: McGraw Hill.

Instituto de Evaluación y Asesoramiento Educativo (2007). Las tecnologías de la información y la Comunicación en la Educación. Informe sobre la implantación y el uso de las TIC en los centros docentes de Educación. Madrid: red.es. Available at: http://www.red.es/media/registrados/2008-

11/1226574461698.pdf?aceptacion=3f8df0fe 25 e7f442ab21871b47bad2f7.

Kessel, van N. et al. (2005). ICT education monitor: eight years of ICT in schools. Holanda: Ministerio de Educación, Cultura y Ciencia.

Korte, W. B., Hüsing, T. (2006). Benchmarking Access and Use of ICT in European Schools 2006: Results from Head Teacher and A Classroom Teacher Surveys in 27 European Countries. Recovered from http://empirica.biz/publikationen/documents/20 06/Learnind_paper_Korte_Huesing_Code_427 _final.pdf.

Marqués, P. (2000). Las TIC y sus aportaciones a la sociedad. Recovered from http://www.redescepalcala.org/inspector/DOCU MENTOS\%20Y\%20LIBROS/TIC/LAS\%20TI C\%20Y\%20SUS\%20APORTACIONES\%20A $\% 20$ LA\%20SOCIEDAD.pdf

Marulanda, K. G., Ramírez, M. M., Londoño, B. M.C., \& López, H. G. (2018). Las TIC como mediación pedagógica y su relación con la autoeficacia en el aprendizaje del inglés como lengua extranjera. Revista de Investigaciones UCM.

DOI:

http://dx.doi.org/10.22383/ri.v18i32.113

Nguyen, L. V. (2010). Computer Mediated Collaborative Learning within a Communicative Language Teaching Approach: A Sociocultural Perspective. The Asian EFL Journal, 12 (1), 202233.
Orellana, N., Almerich, G., Belloch, C. \& Díaz, I. (2004). La actitud del profesorado ante las tic: Un aspecto clave para la integración. Ponencia publicada en Actas del V Encuentro Internacional Anual sobre Educación Virtual Educa, Barcelona. Viewed at: http://www.virtualeduca.org/2004/es/actas/5/1. 5.27.doc.

Organización para la Cooperación y el Desarrollo Económico (OCDE). (2004). Completing the foundation for lifelong learning: An OECD survey of upper secondary schools. París: OECD. Recovered from http: //www.coreched.ch/publikationen/oecd_upp_se cond.pdf

Pastor, M. (2005). La educación superior a distancia en el nuevo contexto tecnológico del siglo XXI. Revista de la Educación Superior, 4(136), 77-93.

Pinto, A., Díaz, J., \& Alfaro, C. (2016). Modelo espiral de competencias docentes TIC, TAC, TEP aplicado al desarrollo de competencias digitales: drive.google.com. Recovered from drive.google.com Web site: https://drive.google.com/drive/folders/1Zc_ISR 255xgIUMmUg5WKNcsmMxs1CK3a

Rodríguez Peñuelas, M. A. (2010). Métodos de investigación. 1ra. Edición, México: Universidad Autónoma de Sinaloa.

Román, V. C. (2017). Aprendizaje de inglés en entornos virtuales. En IV Jornadas de TIC e innovación en el Aula (La plata, 2017).

Saavedra, C., Robledo Gamboa, D. (2016). Ambiente virtual de aprendizaje como herramienta metodológica para el aprendizaje de una segunda lengua-inglés (Doctoral dissertation, Corporación Universitaria Minuto de Dios).

Serra, M., Serrat, E., Solé, R., Bel, A. y Aparici, M. (2000). La adquisición del lenguaje. Barcelona: Ariel.

Soto, L. N. (2019). Virtualidad y presencialidad en el aprendizaje del inglés como lengua extranjera. Recovered from https://ciencia.lasalle.edu.co/lic_lenguas/841 
Unigarro, M. A. (2001). Los conceptos de educación, virtual y educación virtual. En M.A. Unigarro Gutiérrez, Educación virtual. Encuentro formativo en el ciberespacio (págs. 43-60). Bucaramanga: UNAB.

Zuñiga, J. B., Carrasco, P. (2012). Mito dos. La calidad. En G. A. Villegas López, \& M. L. Restrepo Bravo, Diez mitos sobre la educación virtual (págs. 39-51). Medellín: Fondo Editorial Universidad EAFIT 